\title{
Seasonal variation of nutrient content in the foliage of Jatropha curcas
}

\section{Variação sazonal dos teores de nutrientes nas folhas de pinhão-manso}

\author{
Rosiane de Lourdes Silva de Lima ${ }^{1 *}$; Carlos Alberto Vieira de Azevedo ${ }^{2}$; \\ Hans Raj Gheyi ${ }^{2}$; Valdinei Sofiatti ${ }^{3}$; Jairo Osvaldo Cazetta ${ }^{4}$; \\ Genelicio Souza Carvalho Júnior ${ }^{5}$; Nair Helena Castro Arriel ${ }^{3}$
}

\begin{abstract}
Physic nut (Jatropha curcas) is a perennial crop cultivated for the production of oil. Achieving high productivity depends on a profound knowledge of nutritional demand and the appropriate time for fertilization. This study aimed to register the seasonal variation of content of nutrients in leaf and to determine the most suitable time for performing analysis of leaf. For the study, treatments were defined as a factorial combination of 10 months (February, March, April, May, June, August, September, October, November and December) and two provenances of leaf tissues (tissues originating from vegetative branches and coming from fruiting terminals). A completely randomized design was used with four replications and two plants were sampled each time. Foliar concentrations of $\mathrm{N}, \mathrm{P}, \mathrm{K}, \mathrm{Ca}, \mathrm{Mg}, \mathrm{S}, \mathrm{Cu}$, $\mathrm{Fe}, \mathrm{Mn}$ and $\mathrm{Zn}$ showed a wide variation between leaf shedding period through bloom and fruit filling, but the variation was narrow in the period before the leaf shedding phase or the phase of physiological rest. Therefore, the most appropriate time to assess the nutritional status of plants of Jatropha is at the end of the reproductive period during the 30 days preceeding leaf shedding.
\end{abstract}

Key words: Sampling time, mineral nutrition, oilseed crop, Jatropha curcas

\section{Resumo}

O pinhão-manso (Jathopha curcas L.) é uma planta perene cultivada para a produção de óleo. A obtenção de alta produtividade depende do conhecimento das necessidades nutricionais e da época mais apropriada para a adubação das plantas. Este trabalho objetivou registrar a variação sazonal dos teores foliares de nutrientes visando determinar a época mais adequada para realização da análise foliar de plantas de pinhão-manso. Para o estudo definiu-se como tratamentos uma combinação fatorial de 10 meses do ano (fevereiro, março, abril, maio, junho, agosto, setembro, outubro, novembro e dezembro) e duas procedências dos tecidos foliares (tecidos foliares procedentes de ramos vegetativos e tecido foliar procedente de ramos frutíferos). O delineamento experimental foi o inteiramente casualizado com quatro repetições e duas plantas por amostragem. Os teores foliares de $\mathrm{N}, \mathrm{P}, \mathrm{K}, \mathrm{Ca}, \mathrm{Mg}, \mathrm{S}, \mathrm{Cu}, \mathrm{Fe}, \mathrm{Mn}$

${ }^{1}$ Pesquisadora PNPD/CNPq/UFCG, Universidade Federal de Campina Grande, UFCG, Campina Grande, PB, Brasil. E-mail: limarosiane@yahoo.com.br

2 Profs., UFCG, Unidade Acadêmica de Engenharia Agrícola, Campina Grande, PB, Brasil. E-mail: carlos@deag.ufcg.edu.br; hans@agriambi.com.br

3 Pesquisadores, Embrapa Algodão, Campina Grande, PB, Brasil. E-mail: valdinei.sofiatti@embrapa.br; nair.arriel@embrapa.br

${ }^{4}$ Bolsista da Embrapa Algodão, Mestre em Ciências Agrária, Universidade Estadual da Paraíba, UEPB, Campina Grande, PB, Brasil. E-mail: carvalhogenelicio@yahoo.com.br

5 Prof., Dept ${ }^{\circ}$ de Tecnologia, UNESP, Universidade Estadual Paulista “Júlio de Mêsquista Filho", Jaboticabal, SP, Brasil. E-mail: cazetta@fcav.unesp.br

* Author for correspondence 
e Zn apresentaram muita variação entre os períodos de descanso fisiológico, florescimento e intenso enchimento de frutos, mas a variação foi menor na fase que antecede o início do descanso fisiológico. A época mais adequada para avaliar o estado nutricional de plantas de pinhão-manso é no final do período reprodutivo, nos 30 dias que antecedem a queda das folhas.

Palavras-chave: Épocas de amostragem, nutrição mineral, cultura oleaginosa, Jatropha curcas

\section{Introduction}

The physic nut (Jatropha curcas L.) has been recognized as a promising alternative in the production of oil for biodiesel in various countries (MAES et al., 2009; BANGZEN; ZENGFU, 2011; SOUSA et al., 2011; LAVIOLA et al., 2012). This is a perennial crop, whose commercial production begins in the second year after planting and stabilizes from the fourth or fifth year onward (DRUMOND et al., 2010; SILVA et al., 2012).

Although robust, the plant has a slow growth and demonstrates symptoms of nutritional deficiency, which is visible when cultivated in soil poor in macronutrients such as $\mathrm{N}$, P, and K (MAIA et al., 2011), and micronutrients such as $\mathrm{B}, \mathrm{Fe}, \mathrm{Mn}$, and Mo (SILVA et al., 2009). The crop responds to fertilization with nitrogen, phosphorus, and potassium (MARTINS et al., 2009; SOUSA et al., 2011) and to organic fertilization (JUWARKAR et al., 2008; CUEVAS, 2009; KUMAR; SHARMA; MISHRA, 2009). Both these types of fertilization should be performed according to soil fertility. Without fertilization, plants show a slow growth, lower number of branches, and low productivity. Therefore, correct nutrition is essential for its profitable cultivation.

The foliage of the physic nut plant has the following order of nutrient accumulation: $\mathrm{N}>$ $\mathrm{Ca}>\mathrm{K}>\mathrm{Mg}>\mathrm{P}>\mathrm{S}>\mathrm{Mn}>\mathrm{Fe}>\mathrm{B}>\mathrm{Zn}>\mathrm{Cu}$ (LAVIOLA \& DIAS, 2008). During the flowering period, the $\mathrm{N} / \mathrm{K}$ ratio is 2.3 in the leaf and 1.4 in the fruit, indicating that the crop increases its requirement for potassium in the production phase. According to these authors, in a plant that produces $4 \mathrm{~kg}$ of seeds annually, it is estimated that the export of macronutrients $\left(\mathrm{kg} \mathrm{ha}^{-1}\right)$ by fruits is 146 of N, 66 of $\mathrm{P}_{2} \mathrm{O}_{5}, 124$ of $\mathrm{K}_{2} \mathrm{O}, 81$ of $\mathrm{CaO}, 45$ of $\mathrm{MgO}$, and
5 of $\mathrm{S}$. The export of micronutrients $\left(\mathrm{g} \mathrm{ha}^{-1}\right)$ is 162 of B, 75 of $\mathrm{Cu}, 299$ of $\mathrm{Fe}, 667$ of $\mathrm{Mn}$, and 136 of $\mathrm{Zn}$. At this level of production, if an annual nutrient replacement is not performed, soil depletion and reduced production will occur.

The analysis of foliage nutrients complements the measurement of soil nutrients in order to develop recommendations for fertilization. For a correct interpretation of the nutritional state of plants, it is necessary to consider the sampling season because variations in the nutrient content occur throughout the year (MAIER et al., 1995; LIMA et al., 2008).

The physic nut is a perennial plant propagated by seedlings or direct sowing. Fruit production is usually initiated in the first year of production, but it reaches a volume considered commercially viable only between the second and fourth year of cultivation (SEVERINO et al., 2010). At the beginning of the rainy season, new leaves are produced, and after 60 days, the reproductive phase initiates with the flowering phase and fruitfilling. Inflorescences are located in leaf axils and they emerge as the branch grows; due to this, fruit maturation lasts for several months, and since fruits are not retained by the plant, the harvesting process has to be performed in stages, which means every time fruits have matured.

According to Dixon, Elmsly and Dixon (2006) and Lima et al. (2007) the best season for foliage sampling is the season in which nutrients have greater stability in the leaf tissue of a plant, which depends on the demand of the developing organs. Mineral content usually reaches stability at the end of the vegetative growth, when all the nutrients have already reached a lower variation in the leaf tissue (GEORGE; NISSEN; CARSELDINE, 1989).

The highest mineral contents occur during 
flowering, fruit production, and seed filling stages in various species (PESSANHA et al., 2010; HERNANDES et al., 2011; MAIA et al., 2012). Chaudhary, Ghosh and Dick (2009) state that the stability of macro and micronutrients content in the foliage of physic nut crop grown in a region in India depends on the age of the leaf and sampling season. In addition, the highest content of all nutrients usually occurs during the flowering phase and initial formation of the fruits, whereas the lowest contents occur during the seed-filling phase and maturation. In Brazil, there is no available information about the stability of nutrient content across the yearly seasonal changes that could be used to decide on the time of sampling.

This study aims to detect seasonal variation of the nutrient content in the foliage in order to determine the most adequate season to conduct leaf analysis in physic nut plants.

\section{Materials and Methods}

Healthy physic nut plants were selected during their flowering stage from a homogeneous area of four-year-old plants, cultivated at a spacing of $3 \times$ $2 \mathrm{~m}$, and belonging to a plot from Fazenda Estivas, located in the municipality of Garanhuns, PE ( $8^{\circ} 56^{\prime}$ $\mathrm{S}, 36^{\circ} 27^{\prime} \mathrm{W}, 741 \mathrm{~m}$ altitude). The monthly average precipitation in the region is $130 \mathrm{~mm}$, and the climate is semiarid (BS) (dry, semiarid, megathermal, with four rainy months) according to the Köppen classification. The precipitation and temperature that occurred during the year the experiment was carried out are shown in Figure 1.

Figure 1. Precipitation and temperature measured in the year when the experiment was conducted, in 2010, in Garanhuns, PE.

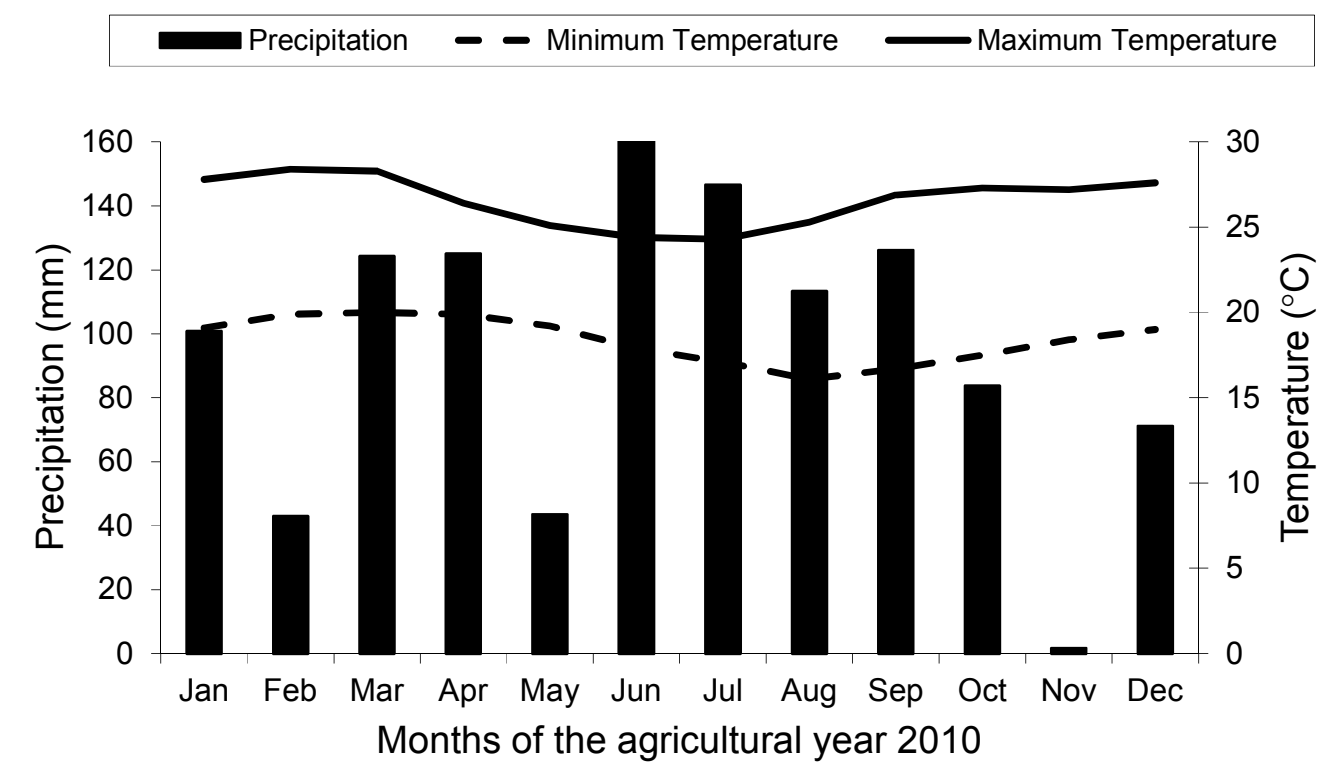

Source: Elaboration of the authors.

The soil in the study area is classified as Neossolo Regolitico (Regosol) of a sandy texture. Samples for the chemical analysis were collected at the depth of 0-20 cm, in the shrubs' canopy projection zone. The samples were homogenized and analysed at the
Irrigation and Salinity Laboratory of the Federal University of Campina Grande (UFCG). The soil was slightly acidic ( $\mathrm{pH}$ 6.2), with high $\mathrm{P}$ content and organic matter, and $76 \%$ of base saturation (Table $1)$, and it was considered of medium fertility. 
Table 1. Soil characteristics in the physic nut crop area.

\begin{tabular}{|c|c|c|c|c|c|c|c|c|c|c|c|}
\hline $\mathrm{pH}$ & $\mathrm{Ca}^{2+}$ & $\mathrm{Mg}^{2+}$ & $\mathrm{Na}^{+}$ & $\mathrm{K}^{+}$ & S & $\mathrm{H}+\mathrm{Al}$ & $\mathrm{Al}^{3+}$ & $\mathrm{T}$ & V & $\mathrm{P}$ & O.M. \\
\hline $1: 2.5$ & & & Exc & $\mathrm{cor}$ & $(\mathrm{mm}$ & $\left(m^{-3}\right)$ & & & $\%$ & $\mathrm{mg} \mathrm{dm}^{-3}$ & $\mathrm{~g} \mathrm{~kg}^{-1}$ \\
\hline 6.2 & 25.7 & 14.3 & 1.47 & 2.3 & 43.7 & 14.0 & 0.5 & 57.7 & 76 & 11.4 & 14.7 \\
\hline
\end{tabular}

S: Sum of bases; T: Effective CEC (T); V: Base saturation; O.M.: organic matter.

Source: Elaboration of the authors.

Liming was not necessary before the sowing of crop in the fields, or in the following years. Meanwhile, throughout the 4 years of production, annual fertilization was carried out by applying $6 \mathrm{t}$ $\mathrm{ha}^{-1}$ of organic matter in the form of cattle manure, in doses recommended by soil analysis.

A completely randomized design was used; the treatments comprised a factorial combination of 10 months of the year (February, March, April, May, June, August, September, October, November, and December in the agricultural year of 2010) and the origin of two types of leaf tissue (leaf tissue from the vegetative branches, and leaf tissue from the fruiting branches), with four replications, and two plants per sampling.

Sampling of plant tissues (except in January and July) was performed monthly throughout 2010. For each sample, 16 leaves located at the fifth position of the vegetative and fruiting branches located at the middle part of the plant canopy were collected in all plants.

The sampled leaves were identified, washed using deionized water to remove impurities, placed in bags, dried in a forced convection oven at $70^{\circ} \mathrm{C}$, milled using a Wiley mill, stored in polyethylene containers with a hermetic seal, and submitted to nitric-perchloric digestion to determine the $\mathrm{P}, \mathrm{K}, \mathrm{Ca}$, $\mathrm{Mg}$, and $\mathrm{S}$ content, and to sulfuric acid digestion digestion to determine the $\mathrm{N}$ content. The samples submitted to sulfuric acid digestion were used in the analyses to determine the nitrogen content according to Jackson (1965), whereas samples prepared by nitric-perchloric digestion were used in the analysis to determine $\mathrm{P}, \mathrm{K}, \mathrm{Ca}, \mathrm{Mg}, \mathrm{S}, \mathrm{Fe}$, $\mathrm{Cu}, \mathrm{Zn}$ and $\mathrm{Mn}$ content (MALAVOLTA; VITTI; OLIVEIRA, 1997).
The $\mathrm{N}$ content was determined by Nessler colorimetric method, $\mathrm{P}$ content by phosphomolybdate reduction with ascorbic acid assay modified by Braga \& Delfelipo (1974), and $\mathrm{K}$ content by flame photometry. $\mathrm{Ca}, \mathrm{Mg}, \mathrm{Cu}, \mathrm{Fe}$, $\mathrm{Mn}$, and $\mathrm{Zn}$ were determined by atomic absorption spectrophotometry, and S by sulfate turbidimetry (BLANCHAR; REHM; CALDWELL, 1963).

Results obtained were submitted to the analysis of variance and Tukey's test $(\mathrm{p}=0.05)$, according to the recommendations by Santos et al. (2008).

\section{Results and Discussion}

In the studied region, the physic nut remains in physiological rest in June and July, initiates its vegetative growth in August, and reaches a peak in flowering and production between September and November. In the remaining cycle, although the plants keep their leaves, produce a small amount of fruits compared to the peak production phase as previously described.

From February to June, we observed that the plants were in their full vegetative growth with a small proportion of flowering and fruit production. The sampling in June and July was marked by an intense leaf shedding, characterized as the phase of physiological rest. During August and the beginning of September, we observed that the vegetative growth resumed and there was a short flowering period of the plant. On the other hand, we observed an intense flowering and fruit production during the sampling period conducted at the end of September and October. In the following sampling period, November and December, the plants were at their final reproductive cycle, in the full grain filling and maturation phase, with a low rate of flowering. 
The macronutrient content differed significantly according to the assessment period and the type of sampled leaf tissue, except for the nutrients $\mathrm{P}, \mathrm{Ca}$, and $\mathrm{Mg}$, which did not differ significantly among the types of leaf tissue. An interaction between the sampling periods and the source of leaf tissue was observed for all the macronutrients that were measured, as shown in Table 2.

Table 2. Summary of the analysis of variance of macronutrients content in different leaf tissues collected in 10 sampling seasons, Garanhuns, PE, 2010.

\begin{tabular}{llllllll}
\hline & \multicolumn{7}{c}{ Mean square } \\
\hline S.V. & D.F & $\mathrm{N}$ & $\mathrm{P}$ & $\mathrm{K}$ & $\mathrm{Ca}$ & $\mathrm{Mg}$ & $\mathrm{S}$ \\
\hline Season (S) & 9 & $201.6^{* *}$ & $15.2^{* *}$ & $38.8^{* *}$ & $65.9^{* *}$ & $28.5^{* *}$ & $0.8^{* *}$ \\
Error (a) & 30 & 18.9 & 0.2 & 1 & 6.5 & 2.0 & 0.03 \\
Leaves (L) & 1 & $59.9^{*}$ & $0.4^{\text {ns }}$ & $48.1^{* *}$ & $1.4^{\text {ns }}$ & $0.06^{\text {ns }}$ & $0.7^{* *}$ \\
S x L & 9 & $43^{* *}$ & $1.7^{* *}$ & $13.6^{* *}$ & $11.6^{* *}$ & $5.9^{* *}$ & $0.5^{* *}$ \\
Error (b) & 30 & 12.7 & 0.2 & 1.0 & 3.6 & 1.0 & 0.03 \\
\hline CV (a) & - & 15.93 & 15.93 & 8.45 & 17.18 & 16.69 & 37.22 \\
CV (b) & - & 13.03 & 16.49 & 8.28 & 12.72 & 11.70 & 36.25 \\
\hline
\end{tabular}

Results of ANOVAs, with the $\mathrm{F}$ test $(\mathrm{F})$ significance, are shown: $* * \mathrm{P}<0.01, * \mathrm{P}<0.05, \mathrm{~ns} \mathrm{P}>0.05$; CV $(\%)=$ Coefficient of Variation. Source: Elaboration of the authors.

The $\mathrm{N}$ and $\mathrm{P}$ content did not differ statistically between the two types of tissue under evaluation, with exception of the samples collected in March for $\mathrm{N}$ content, and samples collected in April and November, which showed significant differences between both minerals' content according to the type of tissue (leaves collected from vegetative branches and fruiting branches). The highest $\mathrm{N}$ and $\mathrm{P}$ contents were reported in leaf tissues collected from fruiting branches (Table 3), confirming the results obtained by Chaudhary, Ghosh and Dick (2009) from adult plants of physic nut cultivated in the semi-arid region of India. Large variations in these nutrients were observed among the evaluated seasons; the highest $\mathrm{N}$ content was observed in the October sampling (41.6-37.3 $\mathrm{g} \mathrm{kg}^{-1}$ ), and the lowest contents of this nutrient was obtained in April and December sampling (21.4-18.2 $\mathrm{g} \mathrm{kg}^{-1}$ ), for vegetative branches (Table 3). The highest $\mathrm{P}$ content was observed in the September and October samplings (5.7-4.7 $\mathrm{g} \mathrm{kg}^{-1}$ ), and the lowest in the February sampling (1.0-0.8 $\mathrm{g} \mathrm{kg}^{-1}$ ). By comparing these results with those cited in the literature and obtained from the adult two-year-old plants, we observed that the $\mathrm{N}$ content obtained in the October sampling was within the range considered as sufficient by Laviola \& Dias (2008), and lower than the results observed by Lima et al. (2011a), which obtained an average $\mathrm{N}$ content of approximately 42.4-42.7 $\mathrm{g} \mathrm{kg}^{-1}$ in leaf tissue collected from fruiting and vegetative branches from the 3.5-year-old plants. According to both studies, the $\mathrm{N}$ content observed in this study is within the range considered sufficient, which is above $30 \mathrm{~g} \mathrm{~kg}^{-1}$ of $\mathrm{N}$.

The $\mathrm{N}$ content obtained in the December sampling was below the range considered sufficient for physic nut crop as cited by Laviola \& Dias (2008) and by Lima et al. (2011 a and b). Despite this nutrient being below the levels considered adequate in the literature, it is important to mention that the levels mentioned above were detected in tissues from plants that were in the fruit production phase and grain-filling phase, whereas the highest levels were observed in plants in their full blooming phase and inflorescence opening. 
Table 3. $\mathrm{N}, \mathrm{P}, \mathrm{K}$, and $\mathrm{Ca}\left(\mathrm{g} \mathrm{kg}^{-1}\right)$ content in the dry mass of physic nut leaves from fruiting branches (RBL) and vegetative branches (VBL) measured in 10 sampling seasons, Garanhuns-PE.

\begin{tabular}{lllllllll}
\hline \multirow{2}{*}{ Seasons } & \multicolumn{9}{c}{ Nitrogen } & \multicolumn{2}{c}{ Phosphorus } & \multicolumn{2}{c}{ Calcium } \\
\cline { 2 - 9 } & \multicolumn{9}{c}{ RBL } & VBL & RBL & VBL & RBL & VBL & RBL & VBL \\
\hline February & BCD 26.4 a & BC 24 a & D 1 a & D 0.8 a & DEF 10.5 a & DE 9.2 a & A 19.2 a & AB 17.4 a \\
March & BCD 28 a & BC 23.2 b & D 1.9 a & BC 2 a & F 8.5 a & DE 8.9 a & AB 18 a & A 19.4 a \\
April & CD 24.4 a & BC 21.4 a & D 1.8 a & CD 1.4 b & EF 8.9 a & E 8.2 a & AB 17.8 a & A 19.9 a \\
May & BCD 26.1 a & BC 25.7 a & C 3.1 a & B 2.5 a & CDE 11 a & CD 11.2 a & ABC 16.5 a & ABC 16.3 a \\
June & BC 30.2 a & ABC 27.2 a & D 1.8 a & CD 1.3 a & CDE 11 a & DE 10.2 a & C 11.4 a & BCD 12.6 a \\
August & BC 30 a & AB 30.1 a & D 1.4 a & CD 1.3 a & A 16.7 a & AB 15.3 a & ABC 14.4 a & AB 16.8 a \\
September & B 32 a & AB 30.0 a & A 5.7 a & A 4.6 a & BC 13.1 a & CD 11.2 b & BC 12.2 a & D 11.2 a \\
October & A 41.6 a & A 37.3 a & B 4.7 a & A 4.7 a & BCD 12.5 a & BC 13.1 a & BC 12.7 a & BCD 13 a \\
November & CD 24.7 a & BC 24.2 a & C 3.1 a & BC 2 b & AB 14.7 a & AB 14.1 a & C 13 a & BCD 12.6 a \\
December & D 21.7 a & C 18.2 a & D 1.9 a & CD 1.5 a & BC 13.3 a & A 16.4 a & C 11.4 a & CD 11.7 a \\
\hline
\end{tabular}

For each element data, means followed by same letter do not differ by Tukey test at $\mathrm{P}=0.05$ (uppercase letters compares means within lines, and lowercase letters within columns).

Source: Elaboration of the authors.

By comparing the P content obtained in this study with those considered adequate from the studies of adult plants of physic nut, we observed that the levels obtained in this study were higher than those observed by Laviola \& Dias (2008) and Lima et al., (2011 a and b), which report P levels above $2.8 \mathrm{~g}$ $\mathrm{kg}^{-1}$ as adequate. By comparing the lowest levels obtained in this study with those mentioned in the studies, level of $\mathrm{P}$ was found to be below the range indicated as adequate. Probably these low contents are due to a decrease of this element in the foliage in response to the intense redistribution to storage organs, and production of fatty acids by seeds during the grain-filling phase and fruit maturation, since $\mathrm{P}$ is part of the phospholipids structure of the cell membranes (MARSCHNER, 2002).

Overall, the $\mathrm{N}$ and $\mathrm{P}$ content in leaves increased gradually from February $\left(25.2 \mathrm{~g} \mathrm{~kg}^{-1}\right.$ of $\mathrm{N}$ and 0.90 $\mathrm{g} \mathrm{kg}^{-1}$ of P) to October (39.45 $\mathrm{g} \mathrm{kg}^{-1}$ of $\mathrm{N}$ and $4.70 \mathrm{~g}$ $\mathrm{kg}^{-1}$ of $\mathrm{P}$ ) (Table 3), which are seasons characterized by an intense vegetative growth and flowering and production peak. The highest foliage content of $\mathrm{N}$ and $\mathrm{P}$ occurred during the intense flowering period of the plants (September/October). Similar results were reported by Chaudhary, Ghosh and Dick (2009), who observed that the highest levels of all the minerals occurred during flowering and fruit production. On the other hand, Lima et al. (2011 a) observed that the highest levels of these two nutrients were obtained in leaf tissue from vegetative branches. When the most intense period of the fruit filling is initiated in the plants (between October and December), the levels of these two nutrients are dramatically reduced (Table 3). Therefore, the lowest $\mathrm{N}$ and $\mathrm{P}$ levels were observed in the December sampling (season characterized by the end of grain filling, complete maturation, and end of cycle). Since N and P are nutrients with high mobility in the phloem, they are promptly redistributed from the source organs to storage organs, decreasing according to the physiological phase (MARSCHNER, 2002; LIMA et al., 2011b).

The $\mathrm{K}$ and $\mathrm{Ca}$ levels were essentially not influenced by the type of leaf tissue, with the exception of the $\mathrm{K}$ content observed in September sampling, which indicated higher levels for these nutrients in the leaf tissue from vegetative branches. According to Lima et al. (2011a), the K content of the leaves is affected by the type of collected tissue, with higher levels found in leaves from vegetative branches. With regard to $\mathrm{Ca}$, the results obtained here were similar to those observed by Lima et al. 
(2011a), who also did not detect any differences in relation to the type of tissue.

There was a significant variation in the amount of these nutrients across the sampling seasons, with higher levels of $\mathrm{K}$ and $\mathrm{Ca}$ observed in August and April samples. In these seasons, the physic nut plants resumed their vegetative growth, and in February, the plants were at the end of their reproductive cycle, in their full grain filling phase and maturation, with a low flowering rate.

The levels of $\mathrm{K}\left(16 \mathrm{~g} \mathrm{~kg}^{-1}\right)$ and $\mathrm{Ca}\left(18.3 \mathrm{~g} \mathrm{~kg}^{-1}\right)$ in the foliage obtained during the vegetative growth phase (August) and beginning of flowering phase (February) were above the levels considered as sufficient according to Laviola \& Dias (2008), which are 13.7 and $19 \mathrm{~g} \mathrm{~kg}^{-1}$ for $\mathrm{K}$ and $\mathrm{Ca}$, respectively. In physic nut plants above 3 years of age cultivated under a non-irrigated conditions, Lima et al. (2011a) observed the average levels of approximately 34.2 $\mathrm{g} \mathrm{kg}^{-1}$ for $\mathrm{K}$, and of $14 \mathrm{~g} \mathrm{~kg}^{-1}$ for Ca. One possible explanation for the increased $\mathrm{Ca}$ levels in February sampling, which is the phase when the plant has decreased levels of most nutrients in the tissues, is that plants were producing new foliage throughout the year, and therefore, leaves collected each month were younger, justifying the decreased level of $\mathrm{Ca}$.

The levels of $\mathrm{K}$ in leaves were approximately $9.85 \mathrm{~g} \mathrm{~kg}^{-1}$ in February (season of intense vegetative growth), reached the highest levels in the beginning of vegetative growth (August sampling) (16.00 $\mathrm{g} \mathrm{kg}^{-1}$, and showed a slight reduction during the intense flowering and fruit filling phase $\left(12.47 \mathrm{~g} \mathrm{~kg}^{-}\right.$ $\left.{ }^{1}\right)$ (September and October sampling). Meanwhile, these levels increased again in December to $14.85 \mathrm{~g}$ $\mathrm{kg}^{-1}$ (end of the plant's reproductive cycle), when the plants still showed vegetative growth but had lower fruit filling (Table 3). Lima et al. (2011 a) observed that the presence or absence of flowers on branches did not influence the potassium level in the foliage of the physic nut plant, which was confirmed in the present study.
The Ca levels decreased gradually throughout the year with no relation to growth phase of the plant (Table 3). The average concentration of $\mathrm{Ca}$ was $18.3 \mathrm{~g} \mathrm{~kg}^{-1}$ in the beginning of the year and 11.6 $\mathrm{g} \mathrm{kg}^{-1}$ at the end of the year (Table 3 ). The vegetative and fruiting branches did not show differences in the concentration of this nutrient. $\mathrm{Ca}$ is an element with low mobility in the phloem, and therefore, has a tendency to accumulate as leaves grow older (MARSCHNER, 2002; LIMA et al., 2011b). Since plants produce new leaves throughout the year, probably the sampled leaves at each month were progressively younger, which partially explains the reduction in Ca content.

The Mg and S content in leaves sustained large variations according to the physiological phases of collected tissues; small differences between the types of leaf tissues under study were also observed (Table 4). Significant differences occurred between levels in leaf tissues obtained from fruiting branches in samples from February, April, and September, and a significant absence was observed in subsequent seasons.

The highest average levels of $\mathrm{Mg}$ and $\mathrm{S}$ were detected in December and October samplings, with approximately $11.25 \mathrm{mg} \mathrm{kg}^{-1}$ of $\mathrm{Mg}$ and $1.33 \mathrm{mg}$ $\mathrm{kg}^{-1}$ of $\mathrm{S}$ (Table 4). These levels were similar to those observed by Laviola \& Dias (2008) and Lima et al. (2011b) in adult physic nut plants in their full flowering and fruit production phases. However, the levels of these two nutrients in August sampling were below the range observed by the authors. From August to the beginning of September, the plants were leaving their physiological rest period and resumed their vegetative growth and flowering of the plant, which was probably why the levels of these nutrients were so low. 
Table 4. Magnesium and sulfur content $\left(\mathrm{g} \mathrm{kg}^{-1}\right)$ in the dry mass of the physic nut leaves from fruiting branches (RBL) and vegetative branches (VBL), measured in 10 sampling seasons, Garanhuns-PE.

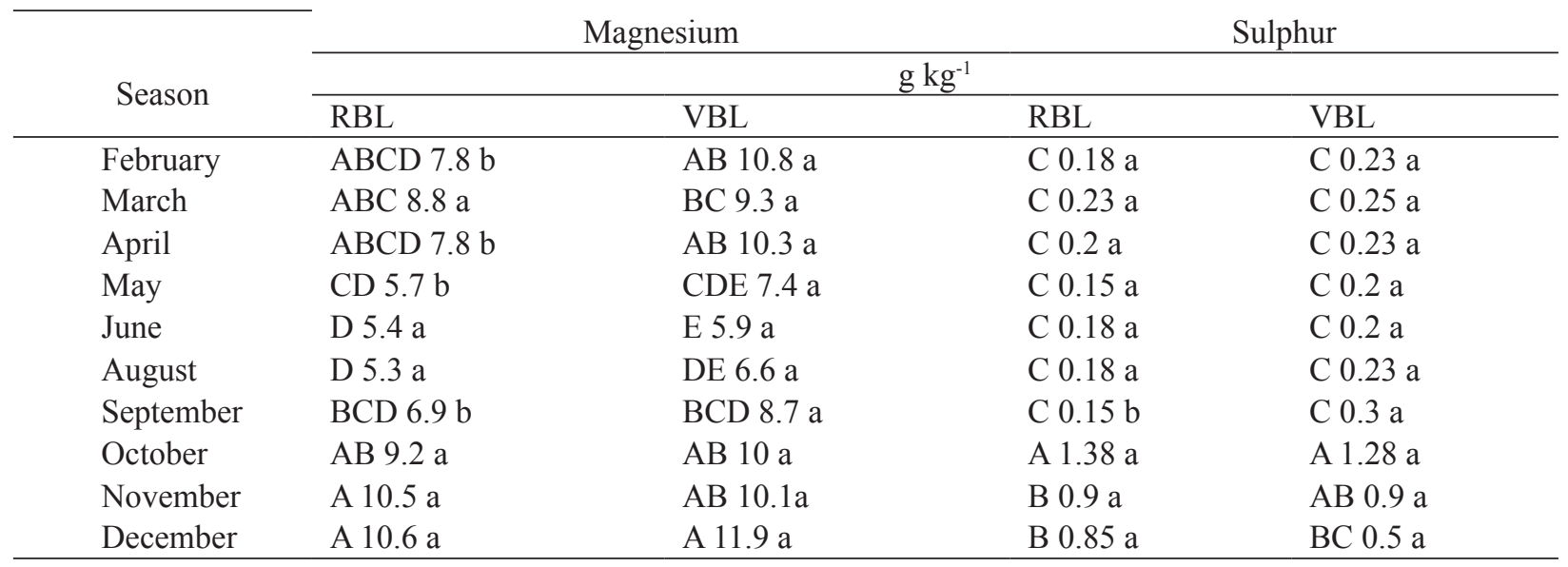

For each element data, means followed by same letter do not differ by Tukey test at $\mathrm{P}=0.05$ (uppercase letters compares means within lines, and lowercase letters within columns).

Source: Elaboration of the authors.

$\mathrm{Mg}$ had lower levels in the middle of the year (August sampling), at $5.3 \mathrm{~g} \mathrm{~kg}^{-1}$ (Table 4). This level increased rapidly after the beginning of the vegetative growth, but it was reduced during the intense flowering and fruit filling phases (between August and November). $\mathrm{Mg}$ is an important constituent of the chlorophyll $\mathrm{a}$ and $\mathrm{b}$ molecules. Therefore, the content of this nutrient in the leaf is associated with the photosynthetic activity, which is low in the physiological rest period and high during the entire period in which a plant has considerable leaf area and high photosynthetic levels.
The levels of S in the foliage (Table 4) were low throughout the year, except in the samples collected in October, November, and December (in the range between 0.15 and $\left.0.25 \mathrm{~g} \mathrm{~kg}^{-1}\right)$; it had a peak (1.28$1.38 \mathrm{~g} \mathrm{~kg}^{-1}$ ) in vegetative and fruiting branches in October, when the fruit filling was more intense.

The micronutrients showed a significant correlation to season and type of leaf tissue, and this was observed for all assessed micronutrients (Table 5).

Table 5. Summary of the analysis of variance of the micronutrient content in different leaf tissues collected in 10 sampling seasons. Garanhuns, PE, 2010.

\begin{tabular}{llllll}
\hline S.V. & D.F & Copper & Iron & Manganese & Zinc \\
\hline Season (S) & 9 & $46.9^{* *}$ & $25411.1^{* *}$ & $799.9^{* *}$ & $161^{* *}$ \\
Error (a) & 30 & 1.0 & 154.9 & 23.1 & 5.7 \\
Leaves (L) & 1 & $55.6^{* *}$ & $149^{\text {ns }}$ & $909.7^{* *}$ & $1.3^{\text {ns }}$ \\
S xL & 9 & $53.1^{* *}$ & $754^{* *}$ & $642.7^{* *}$ & $33^{* *}$ \\
Error (b) & 30 & 0.9 & 189.9 & 29.5 & 8.5 \\
\hline CV (a) & - & 12.55 & 10.74 & 8.43 & 11.56 \\
CV (b) & - & 11.99 & 11.90 & 9.52 & 14.19 \\
\hline
\end{tabular}

Results of ANOVAS, with the $\mathrm{F}$ test $(\mathrm{F})$ significance, are shown: ** $\mathrm{P}<0.01,{ }^{*} \mathrm{P}<0.05, \mathrm{~ns} \mathrm{P}>0.05 ; \mathrm{CV}(\%)=$ Coefficient of Variation. Source: Elaboration of the authors. 
The $\mathrm{Cu}$ content varied according to the type of tissue, in particular in samples collected in March, April, September, October, and November, and the leaves collected from fruiting branches had significantly higher levels of this nutrient when compared to the leaf tissue from vegetative branches (Table 6). High $\mathrm{Cu}$ levels were also reported by Lima et al. (2011a) in leaf tissues collected from fruiting branches. Regarding the seasonal effect, the highest levels of this nutrient were observed in the September sampling for both types of tissues, at 15.2 and $12.7 \mathrm{mg} \mathrm{kg}^{-1}$. On the other hand, the lowest levels were observed in the February sampling, with the average levels of $\mathrm{Cu}$ of $4.1 \mathrm{mg} \mathrm{kg}^{-1}$. By comparing the results obtained in this study with those described in literature, the levels detected in the February sampling were below the range of sufficiency as cited by Laviola \& Dias (2008) and by Lima et al. (2011a and b), which is $10 \mathrm{mg} \mathrm{kg-}^{1}$ in the leaf blade of plants in their full flowering and fruit production phases. One possible explanation for this observation is the fact that the plant was at the end of the cycle and was restarting the vegetative phase.

Table 6. $\mathrm{Cu}, \mathrm{Fe}, \mathrm{Mn}$, and $\mathrm{Zn}$ content $\left(\mathrm{mg} \mathrm{kg}^{-1}\right)$ in the dry mass of the physic nut leaves from fruiting (RBL) and vegetative branches (VBL) measured in 10 sampling seasons, Garanhuns-PE.

\begin{tabular}{lllllllll}
\hline \multirow{2}{*}{ Season } & \multicolumn{2}{c}{ Copper } & \multicolumn{2}{c}{ Iron } & \multicolumn{2}{c}{ Manganese } & Zinc \\
\cline { 2 - 8 } & RBL & VBL & RBL & VBL & RBL & VBL & RBL & VBL \\
\hline February & EF 4.2 a & D 4 a & CD 104.7 a & B 100.9 a & CD 47.6 a & CD 45.4 a & C 15 a & CD 15.2 a \\
March & C 8.4 a & C 6.5 b & C111.2 a & BC 91.5 b & BCD 53.5a & CD 48.7 b & AB 22.2 a & CD 15.7 b \\
April & CD 7.5 a & CD 5.2 b & CD 96.3 a & BC 97.9 a & BCD 52.4 a & CD 52.4 a & BC 16.7 a & D 13.2 b \\
May & A 14 a & A 12.2 a & CD 93.3 a & BC 97.3 a & BCD 55.2 a & C 56.4 a & BC 16.5 a & CD 16.6 a \\
June & DE 6 a & CD 5.9 a & E 53.9 a & D 55.5 a & D 42.9 a & D 44.4 a & A 23.7 a & A 28.5 a \\
August & B 11 a & AB 10.5a & DE 70.9 a & CD 73.3a & B 65.4 b & A 91.3 a & A 25.2 a & AB 23 a \\
September & A 15.2 a & A 12.7 b & CDE 81.8 a & BC 92.4 a & A 78.8 a & B 78.6 a & A 24 b & A 28.3 a \\
October & DEF 5.7 b & B 9.7 a & C 109.9 a & B 110.8 a & BC 57.3 b & B 73.5 a & ABC 21.2 b & A 27.7 a \\
November & F 3.5 b & C 7 a & A 242.5 a & A 218.9 a & D 43 a & CD 50.6 a & AB 22.5 a & BC 19.7 a \\
December & EF 5 a & CD 5 a & B 203.7 a & A 210.2 a & BCD 52.4 a & CD 50.1 & BC 15.9 a & BC 20.5 a \\
\hline
\end{tabular}

For each element data, means followed by same letter do not differ by Tukey test at $\mathrm{P}=0.05$ (uppercase letters compares means within lines, and lowercase letters within columns).

Source: Elaboration of the authors.

The lowest average level of Fe (54.7 $\left.\mathrm{mg} \mathrm{kg}^{-1}\right)$ was observed in June as the physiological rest phase was initiating, increasing slightly in samples from August, September, and October, with average levels of $72.1 \mathrm{mg} \mathrm{kg}^{-1}$ in the beginning of vegetative growth (August) and gradual increases at the end of the intense fruit filling period (Table 6). The iron levels varied also in accordance with the type of leaf tissue, with higher average levels $(242.5 \mathrm{mg}$ $\mathrm{kg}^{-1}$ ) in the leaf tissue from fruiting branches in the November sampling. In this period, the plants were in their full vegetative stage with flowers and fruits present in a small number. Lima et al. (2011a) observed similar levels to the ones observed in the present study in adult physic nut plants. Overall, the highest Fe levels (242.5 and $218.9 \mathrm{mg} \mathrm{kg}^{-1}$ ) were observed in the November sampling, which was characterized by intense physiological processes such as seed filling and maturation. On the other hand, the lowest concentrations of this nutrient occurred in the June sampling, with levels of 53.9$55.5 \mathrm{mg} \mathrm{kg}^{-1}$, which are below $150 \mathrm{mg} \mathrm{kg}^{-1}$ of $\mathrm{Fe}$ considered as adequate for the physic nut plant (LAVIOLA; DIAS, 2008).

The content of $\mathrm{Mn}$ in the foliage from fruiting and vegetative branches varied slightly throughout the year (Table 6), with significant differences only in the samplings from March, August, and 
October. We observed the highest levels in leaf tissues from the vegetative branches, indicating a higher accumulation of this mineral in these organs. The lowest average level of Mn (43.65 mg kg-1) was observed as the physiological rest period was beginning in the plants (June sampling), whereas the highest average level was observed in the September sampling (78.7 $\left.\mathrm{mg} \mathrm{kg}^{-1}\right)$, which is a phase characterized by the emergence of new leaves, inflorescences, blooming, and opening of flowers. In the remaining part of the year, the average levels stabilized at approximately $54.4 \mathrm{mg} \mathrm{kg}^{-1}$. The $\mathrm{Mn}$ content observed in this study was below those observed by Laviola and Dias (2008), which are approximately $314.5 \mathrm{mg} \mathrm{kg}^{-1}$ (Table 6), and were similar to those obtained by Lima et al (2011a and $b$ ) in physic nut plants more than 3 years old. Possibly, among the factors that influenced these results are the age of the plant and the management system, such as fertilization and irrigation. One possible explanation for these results is the absence of defined cultivars for this crop, since the ability for absorption, transport, and redistribution of each nutrient varies according to the genotype (LIMA et al., 2007; 2008). In addition, factors such as soil, fertilization, and precipitation in each region might also influence these results.

Both iron and manganese showed a typical low mobility behavior, in which the content increases as the leaf becomes older. For an appropriate growth of the physic nut these nutrients need to be continuously absorbed and translocated to the growing regions, since in case of deficiency, symptoms would emerge in the youngest leaves.

The foliage $\mathrm{Zn}$ levels were not associated with the growth phase of the plant, similarly to what was observed for $\mathrm{Cu}$. The levels show great variation, without a clear difference between fruiting and vegetative branches, and without a defined behavior in the physiological rest period or in the fruit-filling phase. In the samplings from June, August, and September, the highest peaks of $\mathrm{Zn}$ occurred at approximately $25.45 \mathrm{mg} \mathrm{kg}^{-1}$ and the lowest content of this nutrient was observed in the February sampling at approximately $15.1 \mathrm{mg} \mathrm{kg}^{-1}$. Significant differences in $\mathrm{Zn}$ content were observed in different leaf tissues among samples collected during March and April sampling season, with higher levels in leaf tissues of vegetative branches, whereas in samples collected in September and October, higher levels were found in leaf tissues of fruiting branches. Overall, for the remaining period of the studied seasons, there was no significant difference between the types of leaf tissues, demonstrating that leaf can be collected from any branch to conduct leaf analysis, and the presence of flowers on the branches does not influence the results. These results are below those observed by Lima et al. (2011a) for both types of tissues.

Since the results shown for this nutrient differed greatly from the remaining assessed micronutrients, it is possible that this high level was influenced by an environmental factor that may not be related to the physiology of the plant. $\mathrm{Zn}$ is a low mobility mineral in the phloem and is reduced in the leaf tissue of the physic nut with the aging of the leaf (MARSCHNER, 2002; LIMA et al., 2011b). In younger tissues, the $\mathrm{Zn}$ content in leaves tends to be higher and may undergo occasional variations, with no definitive tendency in the remaining growth phases (LIMA et al., 2011b). During the flowering and fruit formation phases, it is possible that large quantities of this nutrient are translocated from the leaves to the reproductive structures; nevertheless, we observed a high accumulation of $\mathrm{Zn}$ in the tissue of vegetative branches in some of the seasons of the year, demonstrating that this mineral was not translocated to other organs but stored in the leaves collected from the vegetative branches, whereas in the tissues from fruiting branches, the highest levels of $\mathrm{Zn}$ were detected in June and August samplings (23.7 and $25.2 \mathrm{mg} \mathrm{kg}^{-1}$, respectively). According to the literature data, these levels are above the range considered adequate by Laviola \& Dias (2008) and Lima et al. (2011a), which are approximately 22.70 $\mathrm{mg} \mathrm{kg}^{-1}$. 
Copper and zinc are low mobility nutrients in the phloem (MARSCHNER, 2002; EPSTEIN \& BLOOM, 2006; LIMA et al., 2011a), which also showed high levels in the leaves and occasional variations, but with no defined tendency in the remaining physiological stages (Table 6). Zinc levels may have seasonal variations (AMARAL et al., 1998), which might influence part of the variation observed between the phenological stages of the plant.

The best period for conducting the leaf analysis aimed to recommend fertilization is when the nutrients are more stable (CRESSWELL; WICKSON, 1986). In this study, the nutrients sustain the most abrupt alterations between the physiological rest period, and the end of the intense fruit-filling period. After this period, the plants continue their vegetative growth, but with low fruit production. This period that precedes the physiological rest is, therefore, the most adequate season for foliage sampling aimed for chemical analysis and fertilizer recommendation for the majority of nutrients.

\section{Conclusions}

1. The lowest foliage levels of macro and micronutrients occur in the physiological rest period, and the highest levels in the intense flowering and fruit-filling period.

2. The most adequate season to assess the nutritional state of the physic nut plant is the phase before the physiological rest period, when the plants have not yet lost their leaves, but when an intense fruit filling is not occurring.

\section{Acknowledgements}

We acknowledge the National Council of Technological and Scientific Development (CNPq) for awarding a PNPD scholarship to the first author.

\section{References}

AMARAL, J. F. T. Parte da planta e época para diagnose do estado nutricional e crescimento de ramos em aceroleira (Malpighia emarginata D. C.). 1998. Dissertação (Mestrado em Fitotecnia) - Universidade Federal de Viçosa, Viçosa.

CHANG-WEI, L.; KUN, L.; YOU, C.; YONG-YU, S. Floral display and breeding system of Jatropha curcas L. Forestry Studies in China, Kumning, v. 9, n. 2, p. 114$119,2007$.

CHAUDHARY, T. R.; GHOSH, A.; DICK, R. Seasonal variation in the nutrient composition of the foliage of young Jatropha stand. In: INTERNATIONAL ANNUAL MEETINGS, 2009, Pittsburgh. Proceedings... Pittsburgh: ASA-CSSA-SSSA, 2009. p. 1-5.

CUEVAS, V. G. Growth performance of Jatropha curcas L. seedlings and some properties of acidic, low fertility grassland soil amended with biowaste compost. The Philippine Agricultural Scientist, Philippines, v. 92, n. 3, p. 315-319, 2009.

DIXON, J.; ELMSLY, T. A.; DIXON, E. M. Seasonal variations in leaf mineral content. Tauranga-New Zealand, New Zealand Avocado Growers. Association Annual Research Report, Tauranga, v. 6, p. 21-34, 2006.

DRUMOND, M. A.; SANTOS, C. A. F.; OLIVEIRA, V. R.; MARTINS, J. C.; ANJOS, J. B. O.; EVANGELISTA, M. R. V. Desempenho agronomico de genótipos de pinhão-manso no semiárido pernambucano. Ciência Rural, Santa Maria, v. 40, n. 1, p. 44-47, 2010.

EPSTEIN, E.; BLOOM, A. J. Nutrição mineral de plantas: princípios e perspectivas. Londrina: Editora Planta, 2006. 403 p.

FERNANDES, J. D.; CHAVES, L. H. G.; DANTAS, J. P.; SILVA, J. R. P. Fenologia e produção do pinhãomanso cultivado com diferentes fontes de adubação. Revista Ciência Agronômica, v. 44, p. 339-346, 2013.

GEORGE, A. P.; NISSEN, R. J.; CARSELDINE, M. L. Effect of season (vegetative flushing) and leaf position on the leaf nutrient compositon of Annona spp. Hybrid cv. Pink's Mammoth in south-eastern Queensland. Australian Journal of Experimental Agriculture, Collingwood, v. 29, n. 4, p. 587-595, 1989.

HERNANDES, A.; ROZANE, D. E.; SOUZA, H. A.; ROMUALDO, L. M.; NATALE, W. Amostragem para diagnose do estado nutricional e avaliação da fertilidade do solo em caramboleiras. Bragantia, v. 70, n. 3, p. 657663, 2011.

JACKSON, M. L. Soil chemical analysis. New Jersey: Prentice Hall, 1965. 498 p.

JUWARKAR, A. A.; YADAW, S. K.; KUMAR, P.; SINGH, S. K. Effect of biosludge and biofertilizer amendment on growth of Jatropha curcas in heavy metal contaminated soils. Environmetal Monitoring and Assessment, Maine, v. 145, n. 1-3, p. 7-15, 2008. 
KABATA-PENDIAS, A.; PENDIAS, H. Trace elements in soils and plants. 2. ed. Boca Raton: CRC Press, 1992. $315 \mathrm{p}$.

KUMAR, A.; SHARMA, S.; MISHRA, S. Application of farmyard manure and vermicompost on vegetative and generative characteristics of Jatropha curcas. Journal Phyto, Humnabad, v. 1, n. 4, p. 206-212, 2009.

LAVIOLA, B. G.; ALVES, A. A.; GURGEL, F. L.; ROSADO, T. B.; COSTA, R. D.; BARROS, R. R. Estimate of genetic parameters and predicted gains with early selection of physic nut families. Ciência $e$ Agrotecnologia, Lavras, v. 36, n. 2, p. 163-170, 2012.

LAVIOLA, B. G.; DIAS, L. A. S. Teor e acúmulo de nutrientes em folhas e frutos de pinhão manso. Revista Brasileira de Ciência do Solo, Viçosa, MG, v. 32, n. 5, p. 1969-1975, 2008.

LIMA, R. L. S.; FERREIRA, G. B.; WEBER, O. B.; CAZETTA, J. O. Diagnose foliar da gravioleira (Annonamuricata L.): efeito da posição de ramos e folhas. Ciência e Agrotecnologia, Lavras, v.31, p.13201325, 2007.

LIMA, R. L. S.; SEVERINO, L. S.; CAZETTA, J. O.; AZEVEDO, C. A. V.; SOFIATTI, V.; ARRIEL, N. H. C. Posição da folha e estádio fenológico do ramo para análise foliar do pinhão-manso. Revista Brasileira de Engenharia Agrícola e Ambiental, Campina Grande, v. 15, n. 10, p. 1068-1072, 2011 a.

LIMA, R. L. S.; SEVERINO, L. S.; CAZETTA, J. O.; AZEVEDO, C. A. V.; SOFIATTI, V.; ARRIEL, N. H. C. Redistribuição de nutrientes em folhas de pinhãomanso entre estádios fenológicos. Revista Brasileira de Engenharia Agrícola e Ambiental, Campina Grande, v. 15, n. 11, p. 1175-1179, 2011 b.

LIMA, R. L. S.; SIQUEIRA, D. L.; CAZETTA, D. L.; FERREIRA, G. B.; WEBER, O. B. Variação sazonal da concentração de macronutrientes em folhas de diferentes genótipos de aceroleira. Revista Brasileira de Fruticultura, Cruz das Almas, v. 29, n. 3, p. 652-656, 2007.

LIMA, R. L. S.; SIQUEIRA, D. L.; CAZETTA, D. L.; FERREIRA, G. B.; WEBER, O. B.; CAZETTA, J. O.; LOPES, F. F. M. Variação sazonal de micronutrientes em folhas de aceroleira (Malpighia emarginata D.C). Ciência e Agrotecnologia, Lavras, v. 32, n. 3, p. 869-874, 2008.

MAES, W. H.; TRABUCCO, A.; ACHTEN, W. M. J.; MUYS, B. Climatic growing conditions of Jatropha curcas L. Biomass \& Bioenergy, Oxford, v. 33, n. 10, p. 1481-1485, 2009.

MAIA, C. E. Época de amostragem foliar para diagnóstico nutricional em bananeira. Revista Brasileira de Ciência do Solo, Viçosa, MG, v. 36, n. 3, p. 859-864, 2012.
MAIA, J. T. L. S.; GUILHERME, D. O.; PAULINO, M. A. O.; SILVEIRA, H. R. O.; FERNANDES, L. A. Efeito da omissão de macro e micronutrientes no crescimento de pinhão-manso. Revista Caatinga, Mossoró, v. 24, n. 2, p. 174-179, 2011.

MAIER, N. A.; BARTH, G. E.; CECIL, J. C.; CHVYL, W. L.; BARTETZKO, M. N. Effect of sampling time and leaf position on leaf nutrient composition of Protea 'Pink Ice'. Australian Journal of Experimental Agriculture, Collingwood, v. 35, n. 2, p. 275-283, 1995.

MALAVOLTA, E.; VITTI, G. C.; OLIVEIRA, S. A. Avaliação do estado nutricional das plantas: princípios e aplicações. Potafos: Piracicaba, 1997. 319 p.

MARSCHNER, H. Mineral nutrition of higher plants. London: Academic, 2002. 889 p.

MARTINS, L. D.; NOGUEIRA, N. O.; TOMAZ, M. A.; AMARAL, J. F. T.; LAVIOLA, B. G. Efeito do corretivo escória de siderurgia e diferentes adubações no teor nutricional de folhas de mamona e pinhão-manso. Revista Verde de Agroecologia e Desenvolvimento Sustentável, Mossoró, v. 4, n. 4, p. 135-145, 2009.

PEREIRA, J. C. S.; FIDELIS, R. R.; ERASMO, E. A. L.; SANTOS, P. M.; BARROS, H. B.; CARVALHO, G. L. Florescimento e frutificação de genótipos de pinhãomanso sob doses de fósforo no cerrado da Região Sul do Tocantins. Journal of Biotechnology and Biodiversity, Gurupi, v. 2, n. 2, p. 28-36, 2011.

PESSANHA, P. G. O.; VIANA, A. P.; CARVALHO, A. J. C.; OLIVEIRA, J. G. Teores foliares de nutrientes em doze genótipos de videira, Semina: Ciências Agrárias, Londrina, v. 31, n. 4, p. 881-888, 2010.

SANTOS, J. W.; ALMEIDA, F. A. C.; BELTRÃO, N. E. M.; CAVALCANTE, F. B. Estatística experimental aplicada. 2. ed. Revisada e ampliada. Campina Grande: Embrapa Algodão/UFCG, 2008. 461 p.

SILVA, A. P.; MORAIS, D. L. P.; KAKIDA, J.; FERREIRA, E. A.; SILVA, V. F. Concentração do ciclo de produção de pinhão-manso por meio de podas de formação ou de produção. Pesquisa Agropecuária Brasileira, Brasília, v. 47, n. 1, p. 134-137, 2012.

SILVA, E. B.; TANUELI, L. P. P.; SANTOS, S. R.; REZENDE JÚNIOR, P. S. Sintomas visuais de deficiências nutricionais em pinhão-manso. Pesquisa Agropecuária Brasileira, Brasília, v. 44, n. 4, p. 392-397, 2009.

SOUSA, A. E. C.; GHEYI, H. R.; SOARES, F. A. L.; MEDEIROS, E. P.; NASCIMENTO, E. C. S. Teor de óleo no pinhão-manso em função de lâminas de água residuária. Pesquisa Agropecuária Brasileira, Brasília, v. 46, n. 1, p. 108-111, 2011. 